\title{
The Influence of Human Resource Practices on Employee Retention: A Case Study
}

\author{
Vimala Kadiresan (Corresponding author)
}

Faculty of Business, Accountancy and Management, SEGi University, No. 9 Jalan

Teknologi, Taman Sains Selangor, Kota Damansara, PJU5

47810 Petaling Jaya, Selangor D.E. Malaysia

E-mail: vimalakadiresan@ @segi.edu.my

Naail Mohammed Kamil

Faculty of Business, Accountancy and Management, SEGi University, Malaysia

Mohd Rafiq Mohamad Mazlan

Faculty of Business, Accountancy and Management, SEGi University, Malaysia

Mohammed Borhandden Musah

Department of Educational Foundation and Social Science, Faculty of Education

Universiti Teknologi Malaysia, Skudai, Malaysia

Mohamad Hisyam Selamat

Faculty of Business, Accountancy and Management, SEGi University, Malaysia

Received: July 25, 2016 Accepted: September 17, 2016 Published: October 03, 2016 doi:10.5296/ijhrs.v6i3.10093 URL: http://dx.doi.org/10.5296/ijhrs.v6i3.10093

\begin{abstract}
Purpose- The exploratory study investigates the human resource practices that influence employee retention, employing the case study of Albukhary International University (AIU). Design/methodology/approach- Using a non-probability sampling technique, particularly,
\end{abstract}


convenience sampling, the researchers conducted six intensive individual depth interviews (IDIs) from the academics of AIU, Kedah, Malaysia.

Finding - Employing content analysis of rich qualitative data, the results from the intensive IDIs led to some revelations, that in order to encourage employee retention, six recommendations should be considered; organisational strategy, career development, benefits (indirect and non-financial), convenience, organisational commitment, work experience, and fit with Job. The study also proposes that University should place emphasis on psychological contract which can directly lead to improvement in employee engagement.

Implications - Several implications from the research were discussed.

Value/ originality- This study is the first of its kind critically investigating the aspects of employee retention, employee engagement and psychological aspects at AIU in particular and the context of the Private Higher Education Institutions (HEIs) in Malaysia at the larger scale. The findings trigger more research interests among the current and future scholars who might be interested in this field.

Keywords: HR practices, Employee retention, Employee engagement, Psychological contract

\section{Introduction}

Employee retention has gained enormous attention from researchers and practitioners alike in the private and public sectors owing to the positive impacts this construct possesses on organizational development. Yet, there seems to be dearth of research on the determinants of employee retention in contemporary literature particularly in the Malaysian contexts.

In order to be a hub for knowledge and excellence, a university needs a sufficient number of academic staff suitably qualified and motivated to work effectively. The retention and turnover among academicians must be taken seriously by the management of the university. Thus, in order for an education centre to have a dynamic development in the area of teaching and learning as well as in research, it has to initiate the ways and solutions to retain employees, especially its academicians. This is very important for the institution as the priceless knowledge of an academician cannot be replaced. Moreover, the loss of talented academicians may affect the research output and reputation of other Higher Education Institutions (HEIs) in general.

Besides, HEIs regardless of whether it is a public or private institution, is more dependent on its academicians' abilities as compared to other industries (Robyn \& Du Preez, 2013). In countless cases, it has become a challenge to retain well-experienced academic staff that are fittingly qualified to work professionally (Ssekamwa, 1999). The retention and high turnover rate of academicians in the HEIs is a major challenge to these institutions. High employee turnover will have great impacts on the quality and performance of the institution itself.

Turnover can have negative effects on the students and the remaining academicians when a 
position is vacated and is then filled in by an inexperienced academician (Powell, 2010). Moreover, loss of talented academicians might cause a damaging impact on the research output and the image of the institution as HEIs are more dependent on their academic staff's abilities and commitment as compared to other industries (Robyn \& Du Preez, 2013).

As of 2013, Malaysia has 37 private universities, 7 foreign branch campuses, 20 private university-colleges and 414 private colleges (Ministry of Education, 2015). This shows a rising number of HEIs in the country from a year to another. Thus, there is a growing need to have a sufficient number of academicians in all the HEIs in Malaysia.

Albukhary International University (AIU) is a private university and a waqf institution in Malaysia, a fully residential campus with complete facilities and a conducive environment (DRB-HICOM, 2010). AIU offers an all-inclusive education. AIU sits on 80 acres of land at the Sharifah Rokiah Centre of Excellence, and consists of AIU, Souq Albukhary, Masjid Albukhary, an Orphanage, AIU Residence, Dialysis Centre, as well as an old folk's home (DRB-HICOM, 2010). This centre is under the Albukhary Foundation and the main objective is to offer the same opportunity to designated underprivileged students from around the world in improving their livelihood through education (DRB-HICOM, 2010). The university also accommodates 3,000 students at one time and all the students are sponsored and given full scholarship under the Albukhary Foundation. The University consist of $70 \%$ of International students and $30 \%$ of Malaysian students. It has four faculties namely the School of Business Studies, School of Humanities and Social Sciences, School of Computer Science and Information Technology and Centre for Foundation Studies (DRB-HICOM, 2010).

Unfortunately, in January 2014, an incident took place at the university which led to a number of students demonstrating their dissatisfaction on the management of the University (The Voice AIU, 2014). Events took place till February 2014, when the university decided to discontinue some services it used to provide to students.

External consultants had decided that in order to re-organise the management of the university, the university would be closed officially as of June 2014 and all staff (academics and administrative) transferred to other universities in Malaysia. Only few staff would be retained in order to help in the restructuring process. AIU finally withdrew its decision to cease operations in June 2014, stating that the university remains in operation as part of the restructuring process (Bernama, 2014).

In view of this predicament, this study attempts to investigate the human resources practices that may exert influence on employee retention particularly at AIU. The propositions from this exploratory research can be utilized by AIU management, as well as the management of other private or public HEIs in Malaysia or abroad, to justify efforts towards performance improvement interventions so that retention of quality human and intellectual capital can be monitored and further enhanced even at the face of management or economic turbulence or otherwise. 


\section{Literature Review}

\subsection{Employee Retention}

Employee retention is defined as the practices used by organisations to prevent employees from leaving an organisation. Jackson (2013) described employee retention as organisational practices which aimed to retain the bright employees who are highly experienced and difficult to replace and at the same time not easily available in the employment market. According to Johnson (2000), retention is defined as the capability to retain those employees you want to keep, for longer than your competitors with utilising their skills for the organisation performance.

Uma Narang (2013) suggested that organizations should treat their employees as the most valuable assets in order to achieve the organisational goals. Organizations should offer the best strategy in retaining employees such as career growth opportunities, working environment, rewards, supervisory support and work-life balance. Consequently, the employees give their best to the organisation.

Denton (2000) stated that employees who are content and satisfied with their jobs are more dedicated and always put their efforts to progress their organizational customer's satisfaction. Retention starts with recruiting the right people in the first place and continues with training and development as it helps them to give their fullest commitment to the organization (Hytter, 2007). Thus, retaining employees in the organisation rather than hiring is more efficient for the success of the organisation. Walker (2001) elaborated that controlling and retaining talented employees is a vital basic mean of achieving competitive advantage among the organizations.

Panoch (2001) stated that performance-oriented employees are increasingly becoming difficult to find these days and therefore organisations should have a proper strategy in retaining their valuable employees. Moreover, Cascio (2003) explained that an organisation's incapability in preparing and applying suitable strategies of recruiting competent and suitable employees and retaining them is one of the main challenges faced by an organisation.

Employee retention is beneficial to organisations as this helps them to minimise the cost in recruiting and selecting new employees (Kaliprasad, 2006). Beauregard and Henry (2009) assured that for employee retention, implementation of employee retention strategies is essential. Employee retention strategies refer to the strategy formulated by the organisations to retain their competent workforce for performance and therefore one of the suggestions in retaining employees is to keep them motivated (Cutler, 2001).

\subsection{Employee Engagement}

Employee engagement is defined as the highest level of emotional, personal and cognitive involvement of employees on their assigned works, which help them to achieve the goals set by the organisation and eventually help the organisation to achieve exceptional outcomes (Das and Mishra, 2014). Lockwood (2007) defined employee engagement as the employees' commitment for their organisation and how hard work and how long they retain as a result of 
that commitment. He further went on stressing that different organizations may define employee engagement differently. Meanwhile, Harter, Schmidt, and Hayes (2002) defined it as the employee's satisfaction as well as passion for work. Harrison (2007) defined it as the act of employees being involved in, enthusiastic about, and satisfied with their work and he further mentioned that engaged employees are easily motivated and usually put extra efforts on their work. Gubman (2004) stated that engaged employees will perform and stay with their employers, and at the same time mention positive things about them.

Truss et al. (2014) stated that there are some factors that contribute to employee engagement such as job design, content of job, work environment and role of employers. According to Vizzuso (2015), employee engagement gives positive impacts in meeting the organisational goals and the consumer expectations. He further mentioned that organisations can improve employee engagement through employee engagement surveys, auditing systems, establishing a committee to develop a strategy to decrease the power distance, improve trust within the organization, develop hiring strategies, remove employees who are disengaged and hold senior leadership accountable to improve employee engagement, trust, and expectation realisation.

Buckingham and Vosburgh (2001) echoed that one way for an organisation to achieve competitive advantage is through employee engagement. Engaged employees are energetic and passionate on the work they do. Catlette and Hadden (2001) also captured that engaged employees are dedicated and motivated in problem solving and give their fullest commitment on their assigned job. Harter, Schmidt and Hayes (2002) also support this stand by saying that an engaged employee constantly outperforms and strives for excellence.

Fernandez (2007) showed the difference between employee satisfaction and employee engagement, where he mentioned employee satisfaction differs from employee engagement and the employers cannot just depend on employee satisfaction to help retain the best employees in the organisation. However, Macey and Schnieder (2008) disclosed that employee satisfaction is part of employee engagement. Since it reflects on the 'upper layer' of the employee engagement, whereas engagement is more than that. It is about the employees' passion and commitment as well as their enthusiasm in helping the organisations to succeed. Therefore, it can be seen that this is beyond the typical satisfaction on the work that they do as well as the basic loyalty to their employers. Hence, employee engagement can be obtained through job satisfaction and job contribution. Swaminathan and Rajasekaran (2010) contended that employee engagement can only be produced when the elements of job satisfaction, motivation and effectiveness take place in one organisation between the employers and the employees.

\subsection{Psychological Contract}

Psychological contract is a useful concept for understanding the exchange relationships between employees and employers and subsequent consequences which include work attitudes and performance (Turnley \& Feldman, 2000). It comprises the unwritten mutual obligations between the two parties (Bal, 2015). It is also generally seen as the implicit and explicit promises between employers and the employees (Rousseau \& Tijoriwala, 1998) and 
this means the promises can be unwritten and unspoken by being inferred from actions and behaviours of the people in the organisation. In practice, this means psychological contracts are not clearly written in any formal document, yet they strongly affect the way people behave (Conway \& Briner 2009).

Koh et al. (2004) emphasised the importance of psychological aspects of contracts. According to them, psychological contract is different from legal contract because despite the existence of a formal contract between the employee and the employer, individuals develop psychological contracts. Kutaula (2015) argued psychological contracts fulfilment have great positive relationships with human resource practices, frontline management leadership behaviour and co-worker support. In turn, psychological contracts are found to be positively linked to employee outcomes such as affective commitment and job satisfaction. Similarly, Adnan Ahmad and Sumera Khan (2015) contended that breaching the psychological contract harms the organisation, in a way that employees less supported, which may reduce their commitment to work.

Rousseau (1990) identified two major dimensions of psychological contract which are transactional and relational. Transactional contracts are short-term, visible and have an economic focus. Whereas relational contracts are long-term and have a socio-emotional focus and are subjective and implicit in nature. A clear and shared understandings among the employers-employees are important and this is affected by the difficulties in identifying who in the organisation is responsible for delivering the contributions of the organisation (Dabos \& Rousseau, 2004; Guest \& Conway 2000). When an employee assures there is a difference between what was promised and what was received, he/she views this as the organisation's failure to meet the terms of the psychological contract (Turnley \& Feldman 1999). This loosens the employees' engagement and leads to turnover.

\subsection{Human Resource Practices and Employee Retention}

Human resource practices help organisations to retain employees (Tangthong, 2014). There are some ways that help to retain employees such as information sharing, participating in decision making process, compensation system, proper work indicator of employees and career growth through training and development (Tangthong, 2014). Tajammal Hussain and Sheikh Sana ur Rehman (2013) argued that some of the HR practices such as employee-organisation fit, employment security, internal communication system improvement and training and development are important practices in outlining the employee retention. They also stated that HR practices help organisations to retain talented employees.

\subsection{Human Resource Practices and Employee Engagement}

Jose and Mampilly (2012) mentioned that HR practices and employee engagement have a great link that results into organisational success and competitive advantage. Designing suitable HR practices and how these practices could be practised by the employees are the key issues of concern. According to them, the top management should be held responsible to address this matter and take greatest care in fulfilling suitable HR practices that give benefits in terms of employee engagement. HE (2014) mentioned that HR practices help organizations 
in employee engagement. It is essential that employees view HR practices implemented in the organisation as a source of psychological empowerment and high intrinsic motivation that leads to engagement and better job performance.

Therefore, in order to identify and explore how an organisation, specifically the university retains its employees and influences an organisation's performance, it is good to use HR practices as suggested by Pfeffer and Veiga (1998) which consist of seven practices: (1) employment security (2), selective hiring (3), self-managed teams and decentralisation (4), compensation system (5), training and development (6), reduced status distinctions, and (7) information sharing.

\subsection{Employment Security}

Bevan (2012) contended that job security is part of the nine dimensions of 'good work' where the good work is seen as the infrastructure for work, welfare and life quality. Job security is one of the factors for employee motivation, followed by stimulating work, respect and recognition (Purohit and Bandyopadhyay, 2014).

There are nexus between job insecurity, job satisfaction and organisational commitment (Buitendach and Witte, 2005). They go on to say that there are correlations between job insecurity and extrinsic motivation, as well as job satisfaction and job insecurity. Thus, job satisfaction intercedes the relationship between job insecurity and affective organisational commitment.

Employee protection comprises two types; on at-will basis and permanent dismissal barriers (Charness et al., 2014). They then proposed another solution which is on a renewal basis, which is based on current performance. This could help in increasing the employees' productivity, leading to greater profits and higher productivity for organisations, and achieving greater employees' stability and performance simultaneously.

\subsection{Selective Hiring}

Companies that are committed in maximising its profits ensure that they recruit the right people in the first place. Huselid (1995) examined HR practices in high performance companies and found that attracting and selecting the right candidates increases the organizations' productivity and performance, as well as helping in reducing turnover. Organisations need to be clear on what are the most critical skills required in its candidate pool. Other than that, the skills and abilities required need to be carefully considered and consistent with the particular job requirements and the organization's approach to its market.

Selective hiring helps to increase organizational commitment (Nasurdin, Ahmad and Ling, 2015). Therefore, organisations should have clear goals and this enables recruiters to have a better policy in selecting candidates. Employers need a concrete and clear job description during job interview. This helps the candidates to have a better picture and decisions that ultimately lead them to experience greater satisfaction and commitment in the organisation.

Paul and Anantharaman (2003) pointed out that an effective hiring process ensures the presence of employees with the right qualifications, leading to production of quality products 
and consequently increase of economic performance. However, Merkl (2012) mentioned that being too selective implemented by organisations only affects welfare analysis. He went on mentioning that by having selective hiring, increases unemployment rate as there are no organisation wants to hire 'bad' employees.

\subsection{Work Environment}

Sutherland (2004) mentioned that work environment contributes to the main aspect that affects employee's decision whether to stay or leave the job. He also mentioned that the organization must be able to provide better jobs and with great work environment in retaining the employees. According to Winterton (2011) the key aspect in retaining employees is to create a conducive environment of working to the employees.

In Stallworth and Kleiner (1996), work environment is divided into two types namely physical and behavioural. The physical environment may consist of the elements that can connect physically connect the employees with the office environment. Meanwhile, the behavioural environment is how well the employees connect with each other, and the impact of the office environment on the employees' behaviour.

Scott, Jusanne and Steven (2000) identified that work environment does give effects on employees job satisfaction and performance. He disclosed that working conditions has the impacts on the employees' engagement and job satisfaction. Meanwhile in Strong et al. (1999) social, organizational structure, and physical context serve as the drive for jobs assigned, and significantly influence employees' performance. They have also identified safe and healthy working conditions does also give impacts on the employees' job performance.

\subsection{Self-Managed Teams and Decentralisation}

In self-managed team environment, employees are encouraged to contribute their ideas and make important decisions, they have the sense of ownership, as it motivates the employees in performing better (Blakeman. 2014).

As of recent, many organisations require their employees to work in teams and make joint decisions in order to meet the organisation's objectives. Flamholtz and Randle (2000) mentioned organisations that implement a dynamic and faster decision making process help create a better organisation performance and as it grows, having a decentralised decision-making system is essential. Besides that, decentralisation of decision-making process helps increase and motivate employees in any projects assigned to them (Tata \& Prasad, 2004). Singer and Duvall (2000) went on to reiterate that decentralisation is important as it gives benefits and contributes to the HR practices in a given organisation. Collins and Clark (2003) contended that self-managed teams and decentralisation help create organisational competitive advantage and they also give positive impacts on the and firm performance and the HR practices in an organisation.

This shows that the decentralisation system implemented in one organisation does give effects on the firm performance. Batt (2004) found that employees participated in self-managed teams are linked with higher levels of job security, job satisfaction and 
employee engagement. Tata and Prasad (2004) argued that an organisation which implements decentralised decision making helps in having a better work environment for self-managed teams. Self-managed teams together with decentralisation in decision making helps an organisation to reduce employee turnover (Black et al., 2004).

\subsection{Compensation System}

Compensation is defined as the total amount of monetary and non-monetary reimbursement, which is provided by the employers to the employees in return for their works. It comprises three types which are direct financial compensation, indirect financial compensation and non-financial compensation (Chand, 2015).

Collin and Clark (2003) echoed that performance-based compensation is dominantly used for HR practices in evaluating and rewarding employees' productiveness. Delery and Doty (1996) found that a compensation system helps increase employee performance and this is supported by Becker and Gerhart (1996) where they said that there are positive nexus between performance-based compensation and company performance. In addition, incentive compensation has a positive impact on organisational performance, lowers employee turnover and increases sales growth (Batt, 2004).

Performance-based compensation is identified as one of the most effective practices under HR practices (Delery \& Doty, 1996), and considered performance-based compensation as the single strongest predictor of firm performance. HR practices which including compensation have great significant impacts on employee outcomes and corporate performance (Huselid, 1995). This is supported by a study conducted by Teseema and Soeters (2006) where there is a connection between compensation practices and perceived employee performance.

\subsection{Training and Development}

The Chartered Institute of Personnel and Development [CIPD] (2015) reached the conclusion that learning and development helps to develop employee capability, ensure they have the skills, knowledge and behaviour to perform their job, meeting the requirements of the regulatory compliance, achieving organisational goals and development, identifying current and future skills gaps and driving in organisational values.

Competency development or simply known as training and development has a great impact on the firm performance and can be referred to as employees' skills enhancement (Gupta \& Singh, 2010). Boselie, Dietz and Boon (2005) mentioned that employee training is known as the most widely used of HR practices by organisations. Having proper training and development for employees may reduce the cost and risk of selection and recruitment that helps to increase employee productivity and reduce turnover.

An organisation may also assist employees in career growth. This can be done by encouraging employees to take more responsibility for their own development (Doyle, 1997). Besides that, Paul and Anantharaman (2003), found the nexus between HR practices and organisational performance and they proposed that career growth and development programmes prove the concern of the organisation for the growth of its employees, which 
helps stimulate the aspect of commitment and devotion, hence raises the employees' productivity.

\subsection{Information Sharing}

Information sharing helps ensure the right information be received by the right people at the right time to make the right decisions (Burk, 2015). He further illustrated that international organisations value information sharing as the effective means to ensure that wide-ranging project teams communicate efficiently and share vital information.

Information sharing or also known as employee involvement is an essential component for high commitment in an organisation (Marchington \& Wilkinson, 2005). Murphy (2006) defined information sharing as a way to provide employees with necessary information with regards to strategy, targets and goals, financial performance and on ongoing operations along with training to interpret and use this shared information.

Information sharing practices have a great effect on the organisational goals. Similarly, it helps to value employees and develops the sense of mutual trust, which makes the employees feel they are needed to the organisation (Guerrero \& Baraud-Didier, 2004). The open communications within an organisation not only helps to ensure employees are informed on organisational matters, it also signifies that the employees are being trusted by the management in a positive way. Besides that, a great team-working can be produced if the employees are given chances to express and share suggestions which help for improvements in organisational performance.

\subsection{Reduced Status Differences}

Reduction of status differences is defined as the effort done by the organisation in reducing status differences or hierarchies by embracing such policies and values that may decrease the gaps within the organisation (Pfeffer, 1998). This is because status differences are the obstacles in developing and nurturing the relationships among the employers and employees.

It seems that status differences relates to the level of hierarchy. Anderson (2014) suggested four ways to reduce level of hierarchy such as respect the employees at every level, by communicating clearly with them on any office-related matters, inviting them and considering their opinions. Second, good hierarchies are focused and simple which means it can be easily understood and does not excessively control the employees. Third, clearer role and functions that help the employees to know their responsibility and who they are accountable to. The last way, is through collaborative decision making and the employees are accorded with decision-making power within their job scope. This helps reduce power differential in the organisation.

Besides reducing the level of hierarchy, an open-door policy also helps reduce status differences. Miller (2014) argued open-door policy is a way for employees to communicate and give recommendations for the organisation through employers. This gives the opportunity and informs the employees that they have a channel to address their issues. Power differential usually exists between employees and employers, and therefore they need 
to be invited to share their thoughts and opinions with their employers (Nash Consulting, 2014).

\section{Method}

This study employs a qualitative approach in exploring deep rooted meaning that informants ascribe to the constructs. An exploratory design was deliberately made flexible in maximising the collection of intensive and high quality information for the success of the study. In all interactions with informants, the researchers assured no preconceived idea about what responses might be expected. The interview guide was designed to encourage participants to contribute their own ideas and share their experiences with relevant examples and by providing their own experience-based views on the relevant issues.

Furthermore, design as such provides a broad scope to yield potential new insights and establish the groundwork for future studies (Babbie, 2010) on the factors and impacts of employee retention on the university.

\subsection{Qualitative research method}

The in-depth interviews are considered to be the best means to describe and understand informants' views of employee retention in AIU. This is in line with Schaltzman and Strauss' (1973: 89) assertion that "The interview must be used to provide context and meaning". Their justification of the interview as a critical qualitative tool is pertinent to this study. Qualitative methods provides the means to gather details of the solutions from the academicians' point of view to retain employees. The intensely sensed nature and specificity of feedback provided the substance of the study that contributed to affective material for employee retention and their thoughts on the current employer. Employee retention concept is increasingly being presented as a complex phenomenon, and has a number of definitions depending on the individual's experience. The detailed and reflective stories told by informants demonstrated the interaction of various meanings attributed to the concept of employee retention.

\subsection{Sample design}

A sample of six well-experienced academicians from AIU were purposively chosen for the study. The justification for these choices was to explore the aspect of employee retention at AIU and for this, the researchers have decided to choose AIU academic staff as the sample designs for the informants. While the aim of sampling in a survey or experimental study is to select a representative sample of the population for generalisation and prediction purposes, the aim of selecting AIU in this exploratory study was to test new ideas and interpretations. Hence, as stated by Cooper and Schindler (1998) the sample needs not to be representative of a larger population as in the case of survey or experimental studies.

The informants consisted of two males and four females. All of them are Malaysians and full-time academicians in AIU. Face-to-face interviews were conducted and all informants were from different discipline. 


\section{Data collection}

The pre-scheduled personal interviews were conducted at the offices of informants' preferred locations. An informed consent notice was presented to each informant for signing before the start of the interview. The total duration of each interview was $40-50$ minutes. Thus, the total amount of time spent for interview purposes amounted to approximately two hours. A list of questions was used at the beginning of the interview to guide the informants' participation. The questions were open-ended and derived from the literature reviews, a summary of which has been presented in previous sections. The informants were encouraged to express their thoughts freely on the aspects of employee retention. All the interviews were audio recorded and then transcribed at the early stages of the data collection. Notes were also taken during the interviews to capture informants' emotions such as nodding, laughter, smiles, frowns and other indicators, which aided in the data analysis.

\subsection{Data integration and Analysis}

The data collected through interviews were transcribed and then integrated. All the data acquired were examined and categorised recombining the evidence to address the phenomenon understudy. The identity of the informants remained confidential in line with the ethical norms and considerations. A coding process was utilized for this purpose. All of the informants were coded as A1, A2, A3, A4, A5 and A6 correspondingly. The coding process was used to ensure confidentiality of the names and positions of the informants.

\section{Results}

The structure of reporting the results of this exploratory study has been organised in context of the three key issues of concern in this exploratory study. The main issues are: the factors that lead to employee retention at AIU, the factors that lead to employee engagement at AIU and the benefits of psychological contract in helping to engage employees at AIU.

\subsection{Reasons leading to employee retention at AIU}

From the interviews conducted, it can be said that different informants gave different reasons on the decision to remain working at AIU. Some of the reasons are:

"In the beginning, I wanted to come here because... the vision and mission of the university... that was then... then after I came here, I feel that this university has a big potential if we are given the full authority to make our own decisions... power... I should say, we can be a great hub of education in this region." (A1).

“...waiting for a better opportunity... I cannot just quit as I wish unless if I have got an offer already..." (A2).

“... I have worked at other universities for many years already... I think this is the time to go back to my own hometown and serve there..." (A3).

"I am offered with a bigger responsibility now... so I cannot really leave or quit my job as I wish... I need to help the university to settle down some of the problems first then I will consider whether to stay or to fall out." (A4). 
Besides that, Informant (A5) mentioned that:

"As a new lecturer, I need some time to gain experience... it is not the time yet for me to leave this university... I do have the intention but not for the time being".

"I think I am comfortable enough working here... though there are some problems here and there... but overall, I am satisfied... after all, everywhere has its own ups and downs right" (A6).

Based on the responses, all of them gave different reasons for which they have decided to remain working at AIU. This suggests that there are six reasons that lead to employee retention at AIU which are organizational strategy, career development, convenience, organisational commitment, work experience and suitability.

\subsection{Solutions to retain the academicians at AIU}

In order to retain the academicians at AIU, there should be strategies in handling the matter. The academicians have shared their thoughts on the best solutions that the university can do to retain the employees.

Out of six, four of the informants agreed that benefits is one of the solutions:

"Benefits is one of them... benefits in terms of medical coverage... how wide it can be covered in terms of minimum coverage of just hospitalisation or maybe something bigger not just like hospitalisation but also clinic fees, dental coverage, glasses... like... what do you call it... spectacle coverage... how far can it go..." (A1).

"Well, normally if $u$ want to retain the employees it usually about benefits... as a staff, as an employee, I would definitely go for benefits... it is a medical benefits, it is not only the salary... see how devalued money is in this world... it is more to what you can get from the company or the organisation itself" (A2).

"What are the benefits... if they have family so you may want to have a package for the family, for the children, the benefits for schooling for the children... if they are international, you provide international school package... for example, medical benefits... you cover for the whole family members... benefits can be many... for example... salary... you have attractive salary package... benefits in health, welfare of the family members and then... maybe you provide... accommodation for international faculty members... and then... I would say a conducive environment" (A5).

"One of them... Benefits of course..." (A6).

Informants (A1), (A3) and (A5) also stated the importance of work environment as part of the ways in which employees could be retained.

"Not just medical coverage but also in terms of... working environment... like the culture and also the interior... you know if you work in a condensed area with no proper escalation, you would not be able to have an employee... the employee would not be able to have... comfortable area to work in so that would not be good for the motivation of employee... so in 
my opinion it should be comfortable enough to sit from morning till the afternoon... it should be... the lighting should be bright enough so it would be good for the eyes and the space should be... not be too small so that it will be comfortable to move around from one place to another, all those things contribute... contribution to employees as well... if they are motivated, if they are comfortable then they would stay longer" (A1).

“... and I think very important thing is the culture... if people feel like family in the organisation... there is a sense of togetherness... strong bonding... I shall say the work environment does give effects... just imagine when we work in an unpleasant environment... I do not think we can bear it... the culture and the work environment do impact... of course if we are happy with the work and there is job satisfaction, we will not really think on having other jobs" (A3).

“...and... other things... you may want to look at the environment... how you want to make sure the environment is actually worth to work... in the university... work life balance is one thing...”(A5).

Informant (A4) agreed on training and development:

"... The best way is to give training, to upgrade their skills... at least every month there should be a training..." (A4).

In much the same way, informant (A6) mentioned that benefits in terms of providing opportunities to further studies is also essential:

“...opportunity for employees to further studies... as an education institution, the university should provide a better opportunity for lecturers to further their studies... this helps the university in having a better quality of lecturers..." (A6).

Based on the informants' responses, it seems that there are four solutions suggested by the informants in order to retain the academicians at AIU, where Informants (A1), (A3) and (A5) suggested work environment as one of the solutions. Besides that, informants (A1), (A2), (A5) and (A6) agreed that employee benefits will be the ultimate solution. Other than that, Informant (A6) also mentioned opportunity to further studies as another solution and Informant (A4) shared her opinion where training and development is also one of the solutions.

\subsection{Factors that lead to employee engagement at AIU}

In order to retain employees at AIU, there should be effective strategies in handling the matter. The academicians interviewed shared their thoughts on the best solutions that the university can do to retain the employees through employee engagement.

For example, informant (A1) mentioned that:

"I am not sure I am engaged or not... but I think I am satisfied with the work I am doing... Overall, yes... In addition, now less burden... because no students yet... and it is yet to confirm when the university would open ... yes, I am quite satisfied... as of now...". 
"I do like my job... and I will always like my job... because I like teaching... that is my passion... but in term of engagement, I am not really sure... but of course if you like your job, you probably engage with the university..." (A2).

The statement given by Informant (A3) is in line with Informant (A1) where she mentioned she is satisfied with her job:

"Am I engaged? I need to ask my dean whether I was or am engaged or not... as far as I am concern, I have no problems working here... I am satisfied... .”.

In a similar way, another Informant (A4) commented:

"Frankly, I am satisfied with the jobs that I did and do... Just there were some problems before... we need to do a lot of things at one time... that was when I think I was not that really satisfied with

myjob..." (A4).

On the other hand, Informant (A4) also argued that she was assigned with a job that did not really relate to her actual job:

“... We were forced to engage... no choice... my real job is to teach but when I was assigned to other jobs, I felt like I was harassed mentally...

Informant (A4) however suggested one way to engage the academicians at AIU is through the job scope:

"I think one way to engage the employees is by the job itself... it means, it the employees are happy, they will engage... I think... ”.

In much the same way, Informant (A5) also said that she is satisfied with her job:

"I can say I am satisfied with my work... I am waiting for a new opportunity... up to now, I am satisfied... but of course I cannot demand many things as I am still a new lecturer... but in terms of engagement...".

"Yes, I am happy and satisfied... but I am bored now because no students to teach... I really hope the university operates soon..." (A6).

Besides that, two informants, (A5) and (A6) were of the opinion that psychological contract is one of the factors:

“...I think I am engaged because I do not mind doing things out of my real jobs...I am not sure how we can engage the employees... it is very subjective... maybe in terms of the relationship between employers and employees..." (A5).

"In terms of engagement, I did some extra job that was asked by the university... I was ok... I do not mind being attached to other task, as long as it does not affect my real job as a teacher..." (A6). 
Given the informants' it seems that one ultimate factor that leads to employee engagement is psychological contract. All six (6) informants seem to be satisfied with their jobs at AIU. However, in terms of engagement, only informants (A5) and (A6) said that they are engaged with the university, while the other three informants (A1), (A2) and (A3) were not really sure whether they are engaged or not. Unfortunately, there was only one informant (A4) who mentioned that she did not engaged with the university due to job factors but she is satisfied with her job. It worth noting that, out of the six, only three informants disclosed how the university can engage the employees. Informant (A4) mentioned through the job scope and informants (A5) and (A6) mentioned through psychological contracts.

\subsection{Psychological contracts to engage the academicians at AIU}

From the interviews conducted, it can be said that different informants defined and explained their point of view on psychological contracts from different perspectives. However, their explanations are quite similar to one another. Some of their thoughts on psychological contract are:

"From my understanding, psychological contract is a promise made by an employer to the employees that does not have any legal agreement between them... I think it is important because at least the employees feel they are secured working with the employer." (A1).

Because it helps employees feel they are secured while working in the university.

"Psychological contract is an unwritten agreement between the employer and employee. That does not include in the legal contract. I am not really sure... I am an IT Lecturer... I may be wrong... but I think that is it..." (A2).

"It is a verbal agreement... it is something that employers expect from employees and vice versa... and it does not really well explained by the employers to the employees. I think psychological contract is important... it is important because it motivates the employees... I think... such as promotion... salary increment..." (A3).

Informant (A4) responded:

"Psychological contract is.... something which the employers offer in terms of benefits or other necessities to the employees... it is not written well... I think it is more on the promise... in some ways, it is important because at least the promise makes the employees feel motivated in doing works...".

"Is it an unwritten agreement... between employers and employees... the employees may expect something from the employers in return to what they have done... and employers may expect something from their employees as well... I can say... it is important... at least through the contract, some agreement beyond the written one can be fulfilled... Such as promotion..." (A5).

"It can be said as a verbal or indirect agreement between two sides... the employers... the employees... to what extend that employers give their trust... to the employees... and vice versa... it is important at least employees are informed or know what their expectation from 
the employers is and to the employers..." (A6).

It is noteworthy to state that all the informants agreed that psychological contracts are important for employee engagement, thus results and helps for employee retention and there are four HR practices mentioned by the informants that influence employee engagement through psychological contracts such as job security, employee motivation, fulfilment of unwritten agreement and managing expectations.

\section{Discussion of Propositions}

In this study, the researchers used a qualitative research approach to form an in-depth investigation of employee retention in the Private Higher Education Institutions, specifically among the academicians in Malaysia. The results of this exploratory study reflect the employee retention among the academicians in Malaysia particularly at AIU due to the urgency of its situation.

\subsection{Reasons leading to employee retention at AIU}

Based on the interviews, informants were asked why they were still working at AIU. It is evident that all informants have different reasons for which they remain working at AIU.

Informant (A1) stressed that the main purpose was the possibility that the university can be a great hub for higher education in this region. The informant also added joining the university was due to the organisational strategy of the university.

Besides that, another factor that leads to employee retention from the informants' perspectives is waiting for a better opportunity elsewhere. This was stressed by informant (A2) where he pointed out that he had no choice except to wait for a better career opportunity.

Other than that, Informant (A3) stated that she chose to stay at AIU because of personal reasons such as convenience to commute from workplace. However, she does not deny the fact that she may be moving to other places in the future.

Informant (A4) mentioned the reason for her to stay at AIU is because of responsibility. She was offered organisational commitment to help the university in doing some improvement for a better future. She further elaborated that she will consider whether to stay or not once she is done in helping the university for restructuring phase.

Furthermore, Informant (A5) has her own reason for staying at AIU. She made her stand clear that the main reason is because of work experience. This is because as a new lecturer, she needs more experience for her future endeavours. However, she did mention her intention to leave, but not for the time being.

Informant (A6) asserted that the reason for her to remain working at AIU is because she feels she is fit at the place she works and she mentioned that no doubt that she is encountering some problems at AIU. However, she is satisfied with that place.

Taking all together, it seems that there are six factors that help and lead to employee retention at AIU. The factors are organizational strategy, career development, convenience, 
organisational commitment, work experience and fit with job.

\section{Solutions to Retain the Academicians at AIU}

Based on the interviews, the informants suggested four solutions to retain the academicians at AIU. Out of six, Informants (A1), (A2), (A5) and (A6) suggested that employee benefits is one of the solutions. Therefore, compensation can be divided into three types which are direct financial compensation, indirect financial compensation and non-financial compensation (Chand, 2015). This solution in congruent with Pfeffer (1998) who also suggested a three-fold compensation as one of the HR practices. Therefore, the employee benefits will be considered under the non-financial compensation.

The study has also identified training and development as one of the contributing factors for employee retention. This was evident in the words of Informant (A4) that the aspect of training and development is deemed key in an academician retention. In the seven HR Practices by Pfeffer (1998), he included training and development as one of the ways organisations keep hold in order to have a better performance.

Besides that, the study has also identified that work environment does also contribute to employee retention. This was clearly stressed by Informants (A1), (A3) and (A5) that the aspect of work environment and culture is a key element. Even though Pfeffer (1998) did not include work environment as part of the HR practices, it emerged as the factor that contributes to employee retention.

Therefore, it should be noted that there are four solutions suggested by the respondents in order to retain the academicians at AIU:

a) Work environment

b) Employee benefits

c) Opportunity to further studies

d) Training and development

\subsection{Factors leading to employee engagement at AIU}

The findings identified that the respondents reached a consensus that in order to engage the employees, the employers should consider employee satisfaction as one of the solutions to retain employees.

Based on the responses received from the respondents, it seems that all of the respondents are satisfied with their job as teachers. However, in terms of engagement, only two of the respondents (A5) and (A6) responded that they are engaged with the university. At the same time, the other three respondents (A1), (A2) and (A3) did not really sure whether they are engaged or not. Unfortunately, there was only one respondent (A4) which mentioned that she did not engaged with the university due to job factors but however, at the same time she is satisfied with her job.

Besides that, out of six, only two respondents, (A4) and (A5) responded and gave their 
opinions on how the university can engage the employees. Respondent (A4) said that engagement can be achieved through the job scope and at the same time respondent (A5) and (A6) were of the opinion that relationship between the employers and employees can be a factor for employee engagement at the university, which shall be meant as the psychological contracts.

Therefore, it is noteworthy to mention that the two ultimate factors that the university can consider to engage the employees at the university are:

(1) The job scope

(2) Psychological contracts

\subsection{Psychological contracts to engage the academicians at AIU}

From the interviews conducted, it can be said that different respondents defined and explained their point of view on psychological contracts from different perspectives. However, their explanations are quite similar from one another. Therefore, it can be concluded that all of the respondents agreed that psychological contracts are important for employee engagement, thus will result and help for employee retention in the university. All of them gave their justifications on the importance of psychological contracts.

Respondent (A1) indicated that one important thing psychological contracts can help to engage employee is because it will help employees to feel they are secured working in the university. This means once the employees feel secure, they will be loyal to the organisation and at the same time turnover can be reduced.

Besides that, respondent (A3) went on to say that psychological contracts can help to motivate the employees. She mentioned some examples of motivating employees are through offering promotion and increasing salary. This will motivate the employees and once the employees are motivated, it will give a positive outcome for the university. In much the same way, respondent (A4) also disclosed psychological contracts can help to motivate employees in doing their work.

Other than that, respondent (A5) explained that psychological contracts can help the employers to fulfil all the unwritten agreement or promises beyond the written or legal agreement between the employers and employees. One example that she mentioned is through promotion. This means, if the employees performed well, the chance to be promoted is high.

Respondent (A6) also pointed out one important aspect of psychological aspects on employee engagement. By having psychological aspects, the employers and employees will be able to manage their expectations. This means the employers may predict the expectations from the employees, in return of the job that they do and at the same time the employees may predict the expectation by the employers such as by completing their job on time.

It can be said that there are four Human Resource practices that can influence employee engagement through psychological contracts: 


\section{Al Macrothink}

a) Job security

b) Employee motivation

c) Fulfilment of unwritten agreement

d) Managing expectations

\section{Conclusion}

The shortage of academicians is a major problem to the education institution as well as to the country due to the tremendous growth of the industry (Hashim and Mahmood, 2011). Therefore, by conducting this study, solutions can be implemented and it is hoped there will be more follow-up research on the aspect of employee retention and turnover among the academicians specifically at AIU and generally in the Private Higher Education Institutions in Malaysia.

By performing an in-depth interview with selected academicians from AIU, it can be suggested that:

1. There are six reasons that could lead to employee retention at AIU:

a) Organisational strategy

b) Career development

c) Convenience

d) Organisational commitment

e) Work experience

f) Fit with job

2. There are four solutions to retain the academicians at AIU:

a) Work environment

b) Employee benefits

c) Opportunity to further studies

d) Training and development

3. All the respondents are satisfied with their jobs but only two out of six of them are engaged with the university.

4. The two ultimate factors that the university can consider to engage the employees at the university are:

a) The job scope

b) Psychological contracts 


\section{Macrothink}

5. There are four Human Resource practices that influences employee engagement through psychological contracts:

a) Job security

b) Employee motivation

c) Fulfilment of unwritten agreement

d) Managing expectations

Therefore, it is very much hoped that through this in-depth study beneficial references could be made in the future. Since this is the first research on the aspects of employee retention, employee engagement and psychological aspects at AIU and generally in the context of the Private Higher Education Institutions in Malaysia, the findings from this study may trigger more research interests among the current and future scholars who might be interested in this field.

\section{Acknowledgement}

The research is financed by Segi University Kota Damansara. Thanks to the Research and Innovation Management Centre.

\section{References}

Adnan Ahmad \& Sumera Khan. (2015). Psychological Contract Breaches and its Impact on Employee Turnover Intention and Job Satisfaction. Retrieved on September 1, 2015 from http://iiste.org/Journals/index.php/EJBM/article/viewFile/21327/22375

Nasurdin, A. M., Ahmad, N. H. and Ling, T. C. (2015). Linking Selective Hiring to Organizational Commitment: Evidence from the Hotel Industry of Malaysia. Retrieved on $\begin{array}{llll}\text { September } & 1, & 2015 & \text { from }\end{array}$ http://www.shs-conferences.org/articles/shsconf/pdf/2015/05/shsconf_icolass2014_01002.pdf

A. Hytter. (2007). Retention Strategies in France and Sweden, The Irish Journal of Management, Vol. 28, No. 1, Pp. 59-79.

A. Panoch (2001), —The Relationship between Diversity and Employee Retention, Master's Thesis, University of Wisconsin-Stout, Menomonie

Batt, R., 2004. Who Benefits from Teams? Comparing Workers, Supervisors, and Managers, Industrial Relations, 42(1): 183-212.

Becker, B., and Gerhart, B., 1996. The impact of Human Resource Management on organisational performance: Progress and prospects, Academy of Management, 39 (4): 779-801.

Bernama. (2014). AIU withdraws decision to cease operations - Idris. Retrieved on August 25 , 
http://english.astroawani.com/malaysia-news/albukhary-international-university-withdraws-d ecision-cease-operations-idris-34634

Bevan, S. (2012). Good Work, High Performance and Productivity. Retrieved on September 1, 2015 from http://www.theworkfoundation.com/downloadpublication/report/316_good\%20work\%20high $\% 2$ 0performance\%20and\%20productivity.pdf

Black, S.A., Lynch, L.M., and Krivelyova, A., 2004 How Workers Fare When Employers Innovate, Industrial Relations, 43(1): 44-66.

Blakeman, C. (2014). Why Self-Managed Teams Are the Future of Business. Retrieved on September 1, 2015 from http://www.inc.com/chuck-blakeman/why-self-managed-teams-are-the-future-of-business.ht $\mathrm{ml}$

Boselie, P., Dietz, G. \& Boon, C. (2005). Commonalities and contradictions in HRM and performance research. Human Resource Management Journal, 15, 3, 67-94.

Buckingham M \& Vosburgh R (2001). "The 21st Century Human Resources Function: It's the Talent, Stupid!" Human Resource Planning, 24(4): 17-23.

Buitendach, J. H. Witte, H. De, 2005. Job insecurity, extrinsic and intrinsic job satisfaction and affective organisational commitment of maintenance workers in a parastatal, South African Journal Business Management, 36(2).

Burk, M. (2015). Knowledge Management: Everyone Benefits By Sharing Information. $\begin{array}{lllll}\text { Retrieved on } & \text { September } & 1, & 2015 & \text { from }\end{array}$ https://www.fhwa.dot.gov/publications/publicroads/99novdec/km.cf

Catlette, B., \& Hadden, R. (2001). Contented cows give better milk: the plain truth about employee relations and your bottom line. Germantown: Saltillo Publishing

Chand, S. (2015). Compensation: Meaning, System and Objectives of Compensation. $\begin{array}{lllll}\text { Retrieved on } & \text { August } & 22, & \text { from }\end{array}$ http://www.yourarticlelibrary.com/human-resource-development/compensation-meaning-syst em-and-objectives-of-compensation/32366/

Charness, G., Cobo-Reyes, R., Jiménez, N., Lacomba, J. A., \& Lagos F. (2014). Renewable dismissal barriers, job security, and long-term investment: An experimental analysis. $\begin{array}{lllll}\text { Retrieved on } & \text { September } & 1, & 2015 & \text { from }\end{array}$ http://www.econ.ucsb.edu/ charness/papers/dismissal_barriers.pdf

Chartered Institute of Personnel and Development. (2015). Learning and Development 2015. $\begin{array}{llll}\text { Retrieved on } & \text { September } & \text { from }\end{array}$ http://www.cipd.co.uk/binaries/learning-development_2015.pdf

Collins C. J., and Clark K. D., 2003. Strategic human resource practices, top management commitment, team social networks and firm performance: the role of human resource 
practices in creating organizational competitive advantage, Academy of Management Journal, 46(6): 740-751.

Conway, N. \& Briner, R.B. (2009). Fifty years of psychological contract research: What do we know and what are the main challenges? International Review of Industrial and Organizational Psychology, 21, 71-131.

Chand, S. (2015). Compensation: Meaning, System and Objectives of Compensation. $\begin{array}{lllll}\text { Retrieved on } & \text { August } & 22, & \text { from }\end{array}$ http://www.yourarticlelibrary.com/human-resource-development/compensation-meaning-syst em-and-objectives-of-compensation/32366/

Dabos, G. \& Rousseau, D.M. (2004) Mutuality and reciprocity: Psychological contracts in research teams. Journal of Applied Psychology, 89: 52-72.

Delery, J. E, Doty, D. H., 1996. Modes of theorizing in strategic human resource management: tests of universalistic, contingency and configurational performance predictions, Academy of Management Journal, 39(4): 802-835.

Department of Statistic Malaysia (2015). Number of Private Higher Education Institutions in Malaysia. Retrieved July 20, 2015, from http://www.statistics.gov.my/portal/

Doyle, M., 1997. Management development, in Beardwell, I. and Holden, L. eds Human Resource Management: A Contemporary Perspective,. London: Pitman.DRB-HICOM. (2010).

Sharifah Rokiah Centre of Excellence. Retrieved on August 8, 2015 from http://www.drb-hicom.com/cms/publisheddocument/odysseyjuly10.pdf

Flamholtz, E. G., \& Randle, Y. 2000. Growing pains: Transitioning from an entrepreneurship to a professionally managed firm. San Francisco: Jossey-Bass.

Guest, D., \& Conway, R. (2000). The public sector and the psychological contract. IPD Research Report. London: IPD.

Gupta, V. \& Singh, S. (2010). Developing a set of high performance HRM practices and exploring its relationship with OCB and organizational justice.

Gubman, E. (2004). From engagement to passion for work: The search for the missing person. Human Resource Planning

Guerrero, Sylvie and Valérie Barraud-Didier. 2004. High-involvement practices and performance of French firms. International Journal of Human Resource Management 15(8): 1410- 1425.

G. Cutler (2001). Internet Summons Pete to Jump Ship. Research Technology Management.

Harrison, K. (2007). Strategic public relations, a practical guide to success (4th Ed.). Perth: Century Consulting.

Harter, J. K., Schmidt, F. L., \& Hayes, T. L. (2002). Business-unit-level relationship between 
employee satisfaction, employee engagement, and business outcomes: A meta-analysis. Journal of Applied Psychology, 87(2), 268-279.

Hashim, R. A., \& Mahmood, R. (2011). What is the state of job satisfaction among academic staff at Malaysian universities?. UNITAR e-Journal, 7(1).

Jose, G., \& Mampilly, S. R. (2012). Satisfaction with HR Practices and Employee Engagement: A Social Exchange Perspective. Retrieved on September 15, 2015 from http://www.researchgate.net/publication/235790288_Satisfaction_with_HR_Practices_and_ Employee_Engagement_A_Social_Exchange_Perspective_Journal_of_Economics_and_Beha vioural_Studies_7_Vol._4_July_2012

HE, J. (2014). From Employee Perceived HR Practices to Employee Engagement: The Influence of Psychological Empowerment and Intrinsic Motivation. Retrieved on September 25 , 2015

from https://www.google.com/url?sa=t\&rct=j\&q=\&esrc=s\&source=web\&cd=11\&cad=rja\&uact=8 \&ved=0CCYQFjAAOApqFQoTCNfTr-SSnMgCFc5OjgodqocCFw\&url=http\%3A\%2F\%2F www.atlantis-press.com\%2Fphp\%2Fdownload_paper.php\%3Fid\%3D12966\&usg=AFQjCNE orbucfQbIsq9yDNVWgMHgGET9iw\&sig2=f6bk0e31HzVw6AOZJJ8HZw

J. Denton (2000), -Using Web-based projects in a Systems Design and Development Coursell, Journal of Computer Information Systems, Vol. 40, No. 3, Pp. 85-8

J.W. Walker (2001), -Perspectives, Human Resource Planning, Vol. 24, No. 1, Pp. 6-10.

K.M. Morrell, J.L. Clarke \& A.J. Wilkinson (2004), —Organizational Change and Employee Turnover, Personnel Review, Vol. 33, No. 2, Pp. 161-166.

Koh, C., Ang, S., and Straub, D. W. (2004). "IT Outsourcing Success: A Psychological Contract Perspective," Information Systems Research (15:4), pp. 356-373.

Kutaula, S. (2015). Antecedents and Outcomes of Psychological Contract Fulfillment: An Empirical Study Conducted in India. Retrieved on September 1, 2015 from http://orca.cf.ac.uk/70304/1/Smirti\%20Katuala\%20PhD\%202015.pdf

Lockwood, N. R. (2007). Leveraging employee engagement for a competitive advantage. Alexandria, VA: Society for Human Resource Management.

Macey, W. H., \& Schneider, B. (2008). The meaning of employee engagement. Industrial and Organizational Psychology: Perspectives on Science and Practice, 1, 3-30.

Marchington, M. \& Wilkinson, A. (2005). Direct participation and involvement. In S. Bach (Ed.), Managing Human Resources, 4th edn. Oxford: Blackwell, pp. 398-423.

Merkl, C. (2012). Selective Hiring and Welfare Analysis in Labor Market Models. Retrieved on September 1, 2015 from http://www.makro.wiso.uni-erlangen.de/SelectiveHiring.pdf

Miller, B. (2014). Open-Door Policy: What Does It Mean for You? Retrived on September 1, 2015 from http://hrdailyadvisor.blr.com/2014/09/08/open-door-policy-what-does-it-mean-for-you/\# 
Mita Mehta, Aarti Kurbetti \& Ravneeta Dhankhar. (2014). Review Paper - Study on Employee Retention and Commitment. Retrieved on September 1, 2015 from http://www.ijarcsms.com/docs/paper/volume2/issue2/v2i2-0056.pdf

Murphy, D. (2006) "Disclosure and sharing of sensitive information: Revisiting risk in co-operating regulatory regimes", Journal of Financial Crime, Vol. 13 Iss: 4, pp.420 - 441

M. Johnson (2000), - Winning the People War, Talent and the Battle for Human Capitall, Financial Times Management

M. Kaliprasad (2006), - The Human Factor I: Attracting, Retaining, and Motivating Capable Peoplell, Cost Engineering, Vol. 48, No. 6, Pp. 20-26.

Ministry of Education. (2015). Academic Staff in IPTS. Retrieved from http://www.mohe.gov.my/web_statistik/

Nash Consulting (2014). Of "Open Doors" and Approachability. Retrieved on September 1, 2015 from http://www.nashconsulting.com/blog/of-open-doors-and-approachability

Paul, A. K., Anantharaman, R. N., 2003. Impact of people management practices on organizational performance: analysis of a causal model, International Journal of Human Resource Management, 14 (7): 1246-1266.

Pfeffer, J., 1998. Seven practices of successful organizations, California Management Review, 40 (2): $96-124$.

Purohit \& Bandyopadhyay. (2014). Beyond job security and money: driving factors of motivation for government doctors in India. Retrieved on September 1, 2015 from http://www.biomedcentral.com/content/pdf/1478-4491-12-12.pdf

Bal, P. M. (2015). Age and the Psychological Contract. Retrieved on September 1, 2015 from http://www.matthijsbal.com/articles/Bal_2015_Gero.pdf

Robyn, A., \& Du Preez, R. (2013). Intention to quit amongst Generation Y academics in higher education. SA Journal of Industrial Psychology, 39(1), 1-14.

Rousseau, D.M. \& Tijoriwala, S.A. (1998) Assessing psychological contracts: Issues, alternatives, and types of measures. Journal of Organizational Behavior, 19, 679-695.

Rousseau, D. M. (1990). New hire perceptions of their own and their employer's obligations: a study of psychological contracts. Journal of Organisational Behaviour, 11, 389-400.

Das, S. P. \& Mishra, P. S. (2014). Employee Engagement: Developing a Conceptual Framework. Retrieved on August 25, 2015 from http://theijbm.com/june2014/33.BM1406-035.pdf

Schaltzman, L., \& Strauss, A.L. (1973). Field Research: Strategies for a natural sociology, Englewood Cliffs, N.J.: Prentice-Hall.

Singer, J., and Duvall, S. (2000). High-Performance Partnering By Self-Managed Teams In Manufacturing, Engineering Management Journal, 12 (4): 9-15. 
Ssekamwa, J. C. (1999). Lectures in history of education. Kampala: Makerere University School of Education.

Stallworth, J., Kleiner, B. (1996). Recent developments in office design. Journal of Facilities, $14(1 / 2)$, pp. 34-42

Scott, K. D., Jusanne, M., \& Steven, M. E. (2000). Factors influencing employee benefits beliefs that, pay is tied to performance. Journal of Business and Psychology, 14, 553-562

Sutherland, M.M. (2004). Factors affecting the retention of Knowledge Workers. (PhD Dissertation). Faculty of Economics and Management Sciences, University of Johannesburg.

Jackson, S. (2013), "Causes of Attrition of Senior Level Employees: A Study on Selected Commercial Banks of Nepal”, Banking Journal, Vol. 3 No. 2, pp. 37-56.

Swaminathan, J., \& Rajasekaran, D., (2010). Essential components of employee engagement, Advances in Management, 3 (12), 55-59.

Tajammal Hussain \& Sheikh Sana ur Rehman. (2013). Do Human Resource Management Practices Inspire Employees' Retention?. Retrieved on September 25, 2015 from http://maxwellsci.com/print/rjaset/v6-3625-3633.pdf

T.A. Beauregard and L.C. Henry (2009), - Making the Link between Work-Life Balance Practices and Organizational Performancell, Human Resource Management Review, Vol. 19, Pp. 9-22.

Tata, J., and Prasad, S., (2004). Team self-management, organisational structure, and judgments of team effectiveness, Journal of management issues, 16 (2): 248-265.

The Voice AIU. (2014). Student Power. Retrieved on August 25, 2015 from https://www.facebook.com/TheVoiceAiu/posts/498716620241157

Turnley, W. H., \& Feldman, D. C. (1999). The impact of psychological contract violations on exit, voice, loyalty, and neglect. Human Relations, 52, 895-922.

Turnley, W. H., \& Feldman, D. C. (2000). Re-examining the effects of psychological contract violations: Unmet expectations and job dissatisfaction as mediators. Journal of Organizational Behavior, 21, 25-42.

Uma Narang. (2013). HRM Practices - Its Impact on Employee Retention. Retrieved on September 1, 2015 from http://ircjournals.org/vol1issue4/48-51.pdf

Vizzuso, J. D. (2015). Leadership Strategies to Influence Employee Engagement in Health Care. Retrieved on September 1, 2015 from http://scholarworks. waldenu.edu/cgi/viewcontent.cgi?article=1473\&context=dissertations

Walker, R.M., and G.A. Boyne, (2005), Public Management Reform and Organizational Performance: An Empirical Assessment of the UK Labor Government's Public Service Improvement Strategy. Working Paper, Center for Local and Regional Government Research, Cardiff University 


\section{Macrothink}

International Journal of Human Resource Studies

ISSN 2162-3058 2016, Vol. 6, No. 3

Winterton, J. (2011). A conceptual model of Labour Turnover and Retention. Human Resource Development International, 7(3). Scott, D., McMullen, T., and Royal, M. (2012). Retention of Key Talent and the Role of Rewards. Retrieved on August 10, 2015 from http://www.worldatwork.org/waw/adimLink?id=62016

W.F. Cascio (2003), -Managing Human Resources: Productivity, Quality of Work Life, and Profits\|, 6th Edition, Boston: McGraw-Hill, Irwin

\section{Copyright Disclaimer}

Copyright for this article is retained by the author(s), with first publication rights granted to the journal.

This is an open-access article distributed under the terms and conditions of the Creative Commons Attribution license (http://creativecommons.org/licenses/by/3.0/). 